\title{
PERSUADING PEOPLE
}




\section{Persuading People}

\section{An Introduction to Rhetoric}

Robert Cockcroft

Lecturer in English, University of Nottingham

Susan M. Cockcroft

Lecturer in English, Derby Tertiary College, Mackworth

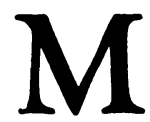

MACMILLAN 
All rights reserved. No reproduction, copy or transmission of this publication may be made without written permission.

No paragraph of this publication may be reproduced, copied or transmitted save with written permission or in accordance with the provisions of the Copyright, Designs and Patents Act 1988, or under the terms of any licence permitting limited copying issued by the Copyright Licensing Agency, 90 Tottenham Court Road, London W1P 9HE.

Any person who does any unauthorised act in relation to this publication may be liable to criminal prosecution and civil claims for damages.

First published 1992 by

THE MACMILLAN PRESS LTD

Houndmills, Basingstoke, Hampshire RG21 2XS

and London

Companies and representatives

throughout the world

Copy-edited and typeset by Grahame \& Grahame Editorial, Brighton

ISBN 978-0-333-47163-0

DOI 10.1007/978-1-349-22254-4

ISBN 978-1-349-22254-4 (eBook)

A catalogue record for this book is available from the British Library 
To our daughters, Hester, Jane and Laura

without whom this might have been finished earlier 


\section{Contents}

Acknowledgements

xi

Introduction: Rhetoric Defined 1

1. Rhetoric: a 'loaded' gun? 1

2. Rhetoric defined 2

3. Rhetoric in history 4

4. Methodology and procedure: 7

(a) Personality and stance (ethos) 8

(b) Emotional engagement (pathos) 9

(c) Modelling and judging argument (logos) 9

(d) Rhetoric and modern linguistic theory 10

(e) Methodology 14

5. An example: The rhetoric of Catch-22 14

\section{PART ONE: THE SOURCES OF PERSUASION}

1 Personality and Stance 17

$\begin{array}{ll}\text { Preface } & 19\end{array}$

1. Personality 20

2. Stance: 21

(a) The persuader and the self 23

(b) The persuader as humourist 23

(c) Persuader and topic 24

(d) Persuader and audience 25

3. Personality and stance in practice: 27

(a) Functional persuasion $\quad 27$

(b) Literary persuasion 33

2 Emotional Engagement 40

Preface: making emotion work $\quad 40$

1. Emotion: universal and contingent 40

2. Emotion and prejudice 43

3. The orientation of emotion 43

4. Actualisation: 45

(a) Graphic vividness $\quad 45$

(b) Emotive abstraction 45 
(c) Communication 45

(d) Actualisation in literary persuasion 46

(e) Actualisation in functional persuasion 47

5. Orientation and engagement: $\quad 48$

(a) Orientation and phatic, metalingual and poetic language: an example $\quad 48$

(b) The emotional laser 49

6. Working with bias and emotion 50

7. Emotional engagement in functional persuasion: 51

(a) Unscripted emotion 51

(b) Political oratory 52

(c) Functional writing: the pamphlet 53

8. Emotional engagement in literary persuasion: 54

(a) Drama $\quad 54$

(b) Poetry 55

(c) Fiction $\quad 56$

Conclusion $\quad 57$

3 Reason: the Resources of Argument 58

Preface: old 'places'; new 'models' $\quad 58$

1. The definition model $\quad 60$

2. Cause and effect models 61

3. The similarity model 64

4. The oppositional model 66

5. The model of degree $\quad 68$

6. The model of testimony 69

7. The genus/species model 71

8. The part/whole model 72

9. The associational model $\quad 74$

10. The root-meaning model 76

4 Reason: Choice and Judgement $\quad 78$

Preface: the context of judgement $\quad 78$

1. What is the issue? $\quad 79$

2. Argument and relevance: $\quad 80$

(a) Relevance and the issue $\quad 80$

(b) Appositeness to audience $\quad 82$

(c) Fitness for the occasion 83

3. Argument and probability 84

4. Rhetorical reasoning: $\quad 87$

(a) The extended enthymeme 87 
(b) Rhetorical induction $\quad 88$

(c) The hypothetical syllogism $\quad 89$

(d) The dilemma 90

(e) The disjunctive syllogism 90

5. Spotting the false argument: 92

(a) Undistributed middle $\quad 92$

(b) Accidental connection $\quad 92$

(c) Ignored qualification $\quad 93$

(d) Missing the point 93

(e) Begging the question 93

(f) False cause $\quad 94$

(g) Many questions $\quad 94$

$\begin{array}{ll}\text { Conclusion } & 94\end{array}$

PART TWO: PERSUASION IN ACTION 95

5 The Persuasive Process $\quad 97$

Preface: ideas of order $\quad 97$

1. Persuasion and the question of genre 98

2. Persuasive ordering: variations and examples: 101

(a) Unscripted discussion 102

(b) The set speech 104

(c) Written argument: commercial persuasion $\quad 106$

(d) Dramatic dialogue 108

(e) Poetry 110

(f) Prose narrative (fiction) 112

$\begin{array}{ll}\text { Conclusion } & 113\end{array}$

6 The Persuasive Repertoire 114

Preface: persuasive style $\quad 114$

1. Lexical choice: $\quad 115$

(a) Literary lexis 115

(b) Non-literary lexis and functional persuasion $\quad 116$

2. Sound patterning 117

3. Figurative language or Trope: 118
(a) Metaphor
118
(b) Metonymy
120
(c) Synecdoche 122
(d) Irony 123
(e) Mislabel (Catachresis) 125 
4. Schematic language: $\quad 125$

(a) Antithesis $\quad 126$

(b) Puns and word-play 126

(c) Syntactic devices $\quad 127$

(d) Repetition 131

(e) Amplification and diminution 132

(f) Tricks and ploys 134

Conclusion: using the repertoire 136

7 Afterword: The Interface - Further Roles for Rhetoric 137

Preface: future options 137

1. The interface of language and literature 137

2. Current critical rhetorics: 139

(a) Popular critical rhetoric 139

(b) Esoteric critical rhetoric 141

3. Eagleton: rhetoric as a political medium 142

4. Bloom: putting rhetoric in its place 145

Conclusion: between critical theory and practice 148

Appendix A: Further Rhetorical Devices $\quad 155$

Appendix B: A Finding List for Rhetorical Devices 158

$\begin{array}{ll}\text { Notes } & 162\end{array}$

$\begin{array}{ll}\text { Select Bibliography } & 172\end{array}$

$\begin{array}{ll}\text { Index } & 175\end{array}$ 


\section{Acknowledgements}

We wish to thank all colleagues in the Department of English Studies at the University of Nottingham, Derby Tertiary College, Wilmorton and Derby Tertiary College, Mackworth who have helped this book to see the light of day. We would particularly like to thank Margaret Berry, Walter Nash and Doris Crick whose examples of scholarly and critical thoroughness have assisted us in our study of the links between language, literature and rhetoric. Professor Alan Sommerstein of the Department of Classics and Dr Peter Boyle of the Department of American Studies at the University of Nottingham are also owed our gratitude for contributions from their particular expertise, as is Professor John Hampton of the Department of Medicine for his happy suggestion of a title, and Natasha Bourne for allowing us to profit from her shrewd analysis of Prime Ministerial rhetoric. We must also thank our friends and family for their encouragement and support over an unconscionably long gestation.

In addition, with our publishers we thank the following for permission to reproduce material: Cambridge University Press and Gordon Wells for a diagram from Learning through Interaction edited by Gordon Wells; Curtis Brown Ltd and the Estate of Sir Winston Churchill for permission to quote from his speeches; Faber and Faber for poems by Philip Larkin ('A Study of Reading Habits') and Sylvia Plath ('Metaphors'); and Penguin Books for extracts from A. N. W. Saunders's translation of Demosthenes. We also gratefully acknowledge permission from K.H.B.B. Advertising Agency and from Toshiba Corporation, Europe, to reproduce the text of advertisements (for the Saab Carlsson CD and the Toshiba 'First Family of Portables', respectively). 